\title{
Design and discrete optimization of hybrid aluminum/composite drive shafts for automotive industry
}

\author{
Bertan Beylergil \\ Department of Mechanical Engineering, Engineering Faculty, Alanya Alaaddin Keykubat University, Antalya, 07450, Turkey \\ bertan.beylergil@alanya.edu.tr
}

Submitted: $15 / 10 / 2019$

Revised: $\quad 07 / 11 / 2020$

Accepted: $01 / 12 / 2020$

\begin{abstract}
Fiber reinforced composites have been widely used in automotive industry since they offer significant weight reduction, low manufacturing and tooling cost, and better integration of parts compared to metal counterparts. In this study, design optimization of a hybrid aluminum/composite drive shaft subjected to torsion was carried out using ANSYS Workbench with ACP module. The numerical validation of finite element (FE) model was carried out by means of theoretical, experimental, and numerical studies in the literature. The ply material, lay-up orientations, and thickness of aluminum layer were considered as design variables. The geometric parameters in design were the length and inner diameter of the drive shaft. Two important design constraints, the minimum first mode natural frequency and design torque, were considered to satisfy the design requirements of a rear-wheel drive shaft used in automotive industry. The optimum design variables were determined by using screening method. The optimum design parameters (length, inner diameter, ply angle, and material) were presented in tabular form. Compared to nonoptimized scenario, the optimized solution reduced the cost of the hybrid composite drive shaft about $30 \%$ without ignoring the design requirements.
\end{abstract}

Keywords: Hybrid; Aluminum/composite drive shaft; Design; Direct optimization; Finite element analysis; Weight; Cost.

\section{INTRODUCTION}

An automotive drive shaft transmits power from the engine to the differential gear of a rear wheel drive vehicle. There are two constraints in the design of automotive drive shafts: (i) the torque capability of the drive shaft for passenger cars should be higher than 3500 N.m; and (ii) the fundamental bending natural frequency should be higher than $9200 \mathrm{rpm}$ to avoid whirling vibration (Reimpell et al., 2001). It is impossible to manufacture one-piece drive shaft by using traditional metals, such as steel, whose fundamental bending frequency higher than $5700 \mathrm{rpm}$. This problem can be solved by replacing traditional drive shafts by hybrid ones. In a hybrid type of aluminum/composite drive shaft, the aluminum transmits the required torque, while the composite layer increases the bending natural frequency above the required frequency value of $9200 \mathrm{rpm}$.

Hybrid glass/carbon fiber (Sevkat et al., 2014; Badie et al., 2011) and hybrid aluminum/composite drive shafts (Lee et al., 2004; Cho et al.,1998) were studied in the literature as an alternative to the composite drive shafts made of carbon fiber or E-glass epoxy layers [6]. In order to improve the plastic deformation ability of drive shafts, Sevkat et al. (2014) suggested to use the combination of glass and carbon fibers reinforcement. Badie et al. (2011) studied the effects of different design parameters such as fiber orientation and stacking sequence of glass and carbon layers on the torsional stiffness, natural frequency, buckling load, and fatigue life of composite tubes, which were investigated. It was stated that carbon fibers are the main constituent that improves the torsional stiffness of the shaft. In addition, 
the fiber orientation should be equal to $45^{\circ}$ to maximize the torsional stiffness. An optimization study by Montagnier and Hochard (2013) came to the same result, so that the plies with 45-degree angle maximize the torque capacity, whereas 0-degree plies maximize the axial stiffness and, therefore, minimize the axial damping. Bijagare et al. (2012) used genetic algorithm to minimize the weight of a composite shaft subjected to constraints applied on the torque transmission and natural frequency.

Rastogi (2004) studied the hybrid composite shaft made of carbon fiber/epoxy and E-glass fiber/epoxy to optimize the cost versus performance requirements. Kim and Lee (2005) studied the optimal design of a press fit joint between the hybrid tube and aluminum yoke of a one-piece hybrid drive shaft. Tariq et al. (2018) investigated the effect of hybrid reinforcement on the performance of filament wound hollow shaft. The hybrid shafts are composed of hybrid filaments including a combination of carbon, glass, and aramid fibers. They showed that carbon fiber reinforcement shows best results in terms of torsional characteristics. The hybridization effect was also studied by other researchers; on the other hand, the direct optimization together with finite element analysis (FEA) for the design of aluminum/composite drive shafts was not studied in the literature. Further research is needed in order to provide better understanding of the finite element modeling and design optimization procedure of these hybrid composite shafts using the direct optimization. In this study, a design optimization procedure based on screening method combined with the finite element method was introduced and applied to the robust design of aluminum/composite hybrid shafts.

In this work, the design optimization of a hybrid aluminum/composite drive shaft subjected to torsion was carried out using direct optimization technique. The ply material, lay-up orientations, and the thickness of aluminum layer were considered as design variables. Three important design constraints, the minimum first mode natural frequency, design torque, and Tsai-Wu failure index, were considered to satisfy the design requirements of a rear-wheel drive shaft used in the automotive industry. The objective function is to minimize the cost and weight by considering the specified design requirements to be met, while balancing the weight savings with minimum cost. The numerical analyses were carried out by using ANSYS Workbench with ACP module. The numerical results were first validated against theoretical, experimental, and numerical studies in the literature; then, the FE model was extended to the present study.

\section{NUMERICAL VERIFICATION}

In order to validate of the numerical model, the results of present study were compared with the theoretical, experimental, and numerical results obtained by other researchers. Bauchau et al. (1998) performed torsional buckling experiments and analytical calculations for the thin-walled composite tubes having different fiber orientations. Shokrieh et al. (2004) investigated shear buckling of composite drive shafts under pure torsion both analytically and numerically. Bert and Kim (1995) analyzed buckling of hollow laminated composite drive shafts analytically and compared their results with those of presented by Bauchau et al. (1988). In other investigations by Khalkhali et al. (2015) and Talib et al. (2010), the critical buckling torque and natural frequencies of hybrid composite drive shafts were presented both analytically and numerically for different fiber orientations. The numerical verification of this study was carried out by comparing the results presented by the aforementioned researchers with the obtained numerical results. Numerical analyses of the composite tubes subjected to torsion were performed using ANSYS Workbench with ACP module. Figure 1 shows the project schematic developed in ANSYS for the verification.

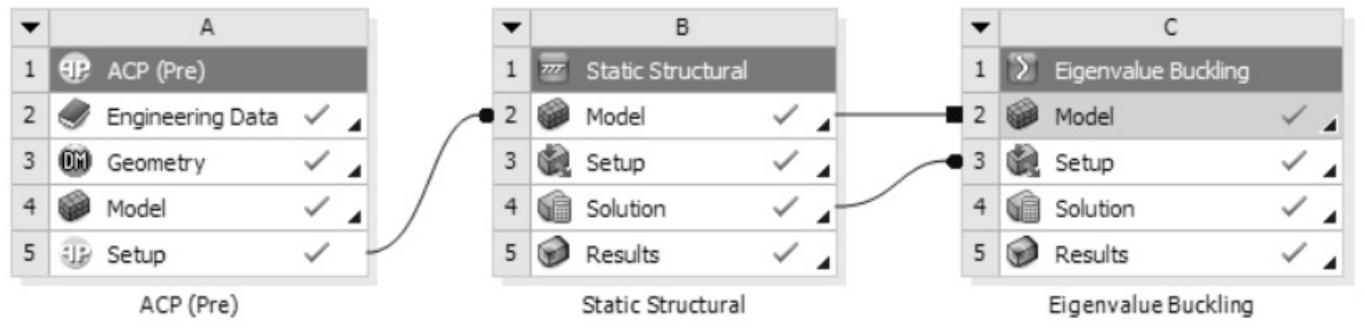

Figure 1. Project schematic developed in ANSYS Workbench. 
The first step was to enter the mechanical properties of composite plies given in Table 1. Then, 2D geometric model of the composite tube was created. The second step involves meshing of 2D surface and the entering of the number of plies, the thickness, and the orientation of each ply using ACP-module. The 3D finite element model of the composite tube (Figure 2a) was created. In total, 100608 SOLID186 elements having 118272 nodes were used. One element was used for each ply (6 elements through the thickness) while creating 3D model of the composite tube. Then, the boundary and loading conditions were applied to the 3D finite element model by creating two cylindrical coordinate systems $(\mathrm{r}, \Theta, \mathrm{z})$ at the ends of the composite tube. Figure $2 \mathrm{~b}$ shows the boundary and loading conditions used for the torsional buckling of the composite tube. One end was fixed in both translation and rotation in $\mathrm{x}, \mathrm{y}$, and $\mathrm{z}$ axes, whereas the translation was fixed in the $\mathrm{x}$-axis.

Table 1. Mechanical properties of carbon fiber/epoxy and glass fiber/epoxy composites.

\begin{tabular}{|c|c|c|c|c|c|}
\hline Reference & Type & $\mathbf{E}_{\mathbf{1}}(\mathbf{G P a})$ & $\mathbf{E}_{\mathbf{2}}(\mathbf{G P a})$ & $\mathbf{G}_{\mathbf{1 2}}(\mathbf{G P a})$ & $\mathbf{v}_{\mathbf{1 2}}(\mathbf{G P a})$ \\
\hline $\begin{array}{c}\text { Bauchau et al. (1988), Shokrieh et al. (2004) } \\
\text { and Bert and Kim (1995). }\end{array}$ & CF-EP & 134.0 & 8.5 & 4.6 & 0.29 \\
\hline $\begin{array}{c}\text { Talib et al. (2010), } \\
\text { Khalkhali et al. (2015). }\end{array}$ & CF-EP & 126.9 & 11.0 & 6.6 & 0.30 \\
\hline $\begin{array}{c}\text { Talib et al. (2010), } \\
\text { Khalkhali et al. (2015). }\end{array}$ & EG-EP & 40.3 & 6.21 & 3.07 & 0.30 \\
\hline
\end{tabular}

GF-EP: Glass fiber/epoxy, CF-EP: carbon fiber/epoxy.

Figure 3 shows the first mode of torsional buckling of the composite tube having [15/-15/-45/15/15/45] and [-45/-15/15/45/15/-15] lay-up orientation. The critical torsional buckling loads of [15/-15/-45/15/15/45] and [-45/15/15/45/15/-15] composite tubes were determined as 478.55 N.m and 392.1 N.m, respectively. One can see these values as load-multiplier in Figure 3. Table 2 shows the comparisons of critical buckling torques. As can be seen, the predicted buckling load showed a good agreement with those reported in the literature. By comparing these results with the experimental results in Table 2, the critical buckling load obtained in this study showed better agreement with the experimental results.

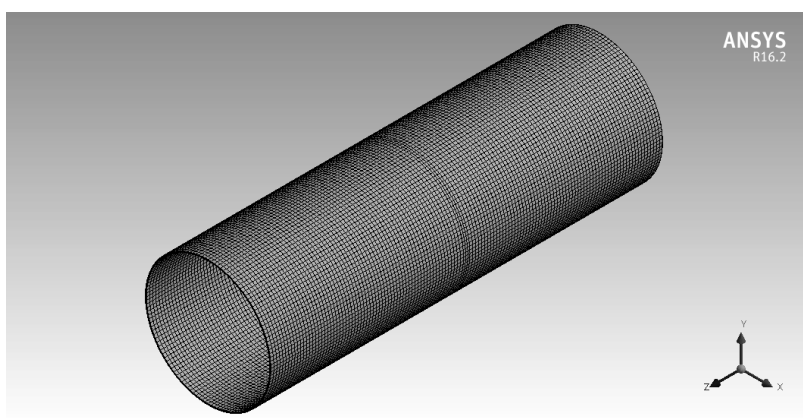

(a)

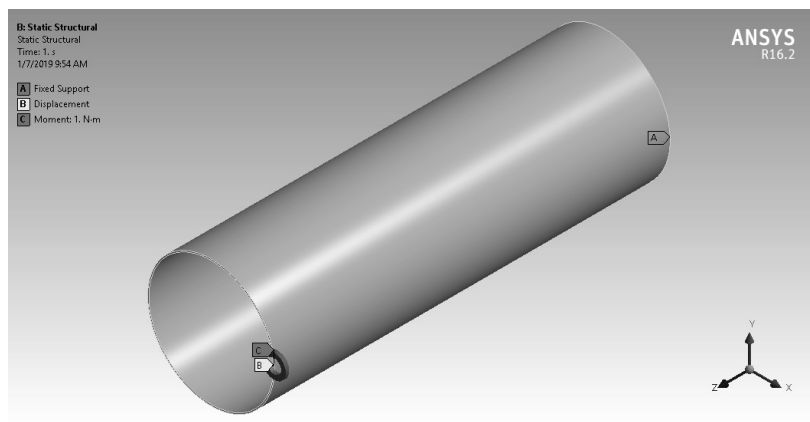

(b)

Figure 2. (a) 3D finite element model of composite tube and (b) the applied boundary and loading conditions.

Table 3 shows the 1 st mode natural frequency values (in $\mathrm{Hz}$ ) of hybrid composite shafts for different lay-up orientations. The results were compared with those reported by Talib et al. (2010). Numerical error was below 1\% for every different lay-up orientations considered. Therefore, it can said that this FE model can be correctly used for 
determining the natural frequency values of hybrid composite shafts made of different ply materials such as carbon fiber/epoxy and glass fiber/epoxy. Figure 4 shows the first mode natural frequencies of hybrid composite shafts for different orientations.

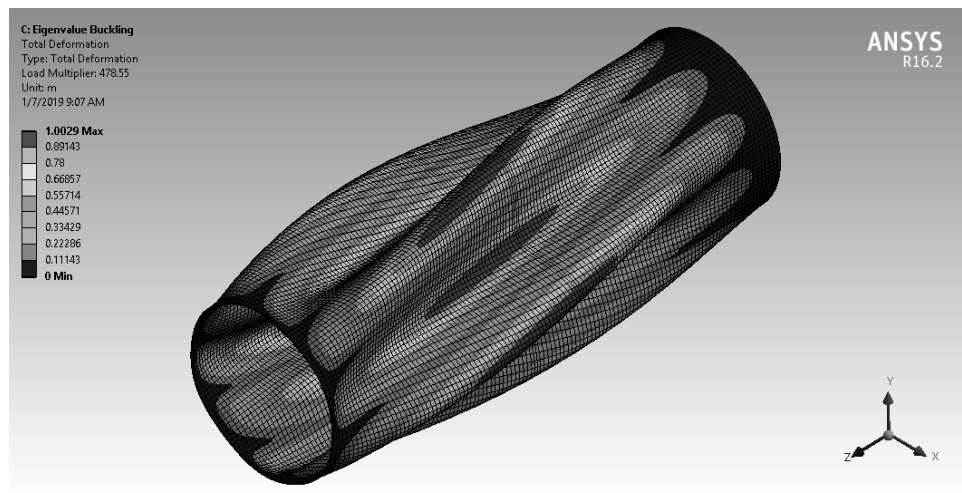

(a)

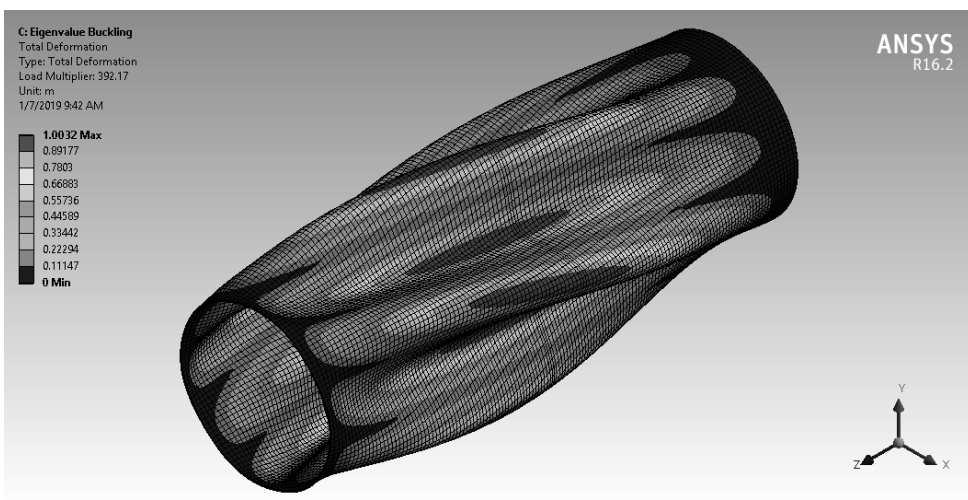

(b)

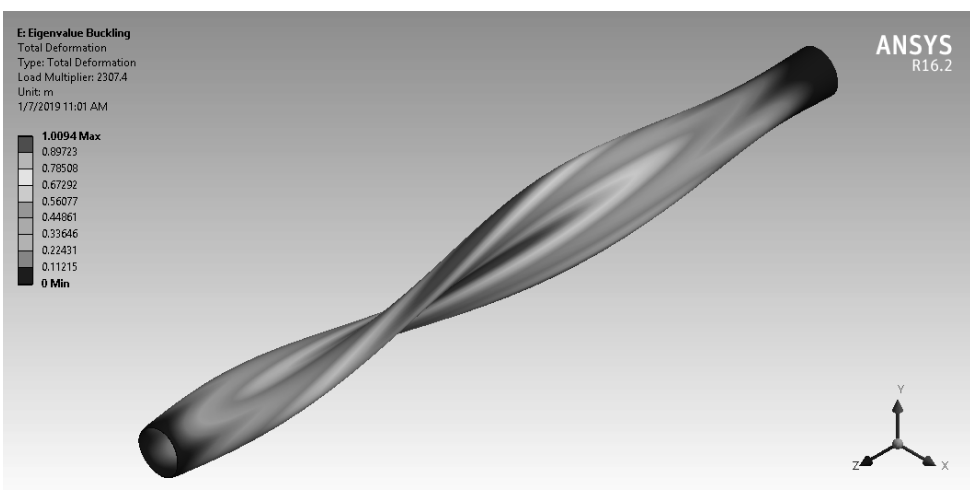

(c)

Figure 3. First mode of torsional buckling of the composite tube (a) Lay-up orientation: [15/-15/-45/15/15/45], (b) Lay-up orientation: [-45/-15/15/45/15/-15] and (c) Lay-up orientation: $\left[45_{\text {GF-EP }} /-45_{\text {GF-EP }} / 0_{\text {CF-EP }} / 90_{\text {GF-EP }}\right]$. 
Table 2. Comparisons of critical buckling torques.

\begin{tabular}{|c|c|c|c|c|c|}
\hline Reference & $\begin{array}{c}\mathrm{L} \\
\text { (Length, } \mathrm{m})\end{array}$ & $\begin{array}{c}\quad R \\
\text { (Mean shaft } \\
\text { radius, mm) }\end{array}$ & $\begin{array}{l}\text { Lay-up definition (starting } \\
\text { from innermost ply) }\end{array}$ & $\begin{array}{c}\text { Buckling } \\
\text { torque (N.m) }\end{array}$ & $\begin{array}{c}\text { Present } \\
\text { prediction } \\
\text { Buckling } \\
\text { torque (N.m) }\end{array}$ \\
\hline $\begin{array}{l}\text { Bauchau et al. } \\
\text { (1988) }\end{array}$ & 0.26 & 41.27 & {$[15 /-15 /-45 / 15 / 15 / 45]$} & $486^{1}$ & \multirow{4}{*}{$478.5^{3}$} \\
\hline $\begin{array}{l}\text { Bauchau et al. } \\
\qquad(1988)\end{array}$ & 0.26 & 41.27 & {$[15 /-15 /-45 / 15 / 15 / 45]$} & $523^{2}$ & \\
\hline $\begin{array}{l}\text { Shokrieh et al. } \\
\qquad(2004)\end{array}$ & 0.26 & 41.27 & {$[15 /-15 /-45 /-15 / 15 / 45]$} & $472^{3}$ & \\
\hline $\begin{array}{l}\text { Bert and Kim } \\
\quad(1995)\end{array}$ & 0.26 & 41.27 & {$[15 /-15 /-45 /-15 / 15 / 45]$} & $535^{2}$ & \\
\hline $\begin{array}{c}\text { Bauchau et al. } \\
\text { (1988) }\end{array}$ & 0.26 & 41.27 & {$[-45 /-15 / 15 / 45 / 15 /-15]$} & $350^{1}$ & \multirow{4}{*}{$392^{3}$} \\
\hline $\begin{array}{l}\text { Bauchau et al. } \\
\text { (1988) }\end{array}$ & 0.26 & 41.27 & {$[-45 /-15 / 15 / 45 / 15 /-15]$} & $366^{2}$ & \\
\hline $\begin{array}{l}\text { Shokrieh et al. } \\
\qquad(2004)\end{array}$ & 0.26 & 41.27 & {$[-45 /-15 / 15 / 45 / 15 /-15]$} & $372^{3}$ & \\
\hline $\begin{array}{l}\text { Bert and Kim } \\
\quad(1995)\end{array}$ & 0.26 & 41.27 & {$[-45 /-15 / 15 / 45 / 15 /-15]$} & $382^{2}$ & \\
\hline $\begin{array}{l}\text { Talib et al. } \\
\text { (2010) }\end{array}$ & 1.73 & 50.30 & {$\left[45_{\text {GF-EP }} /-45_{\text {GF-EP }} / 0_{\text {CF-EP }} / 90_{\text {GF-EP }}\right]$} & $2303.1^{2}$ & $2307.4^{3}$ \\
\hline $\begin{array}{l}\text { Khalkhali et al. } \\
\text { (2015) }\end{array}$ & 1.73 & 50.30 & {$\left[45_{\text {GF-EP }} /-45_{\text {GF-EP }} / 0_{\text {CF-EP }} / 90_{\text {GF-EP }}\right]$} & $2327^{3}$ & $2307.4^{3}$ \\
\hline
\end{tabular}

1: Experimental, 2: Theoretical, 3: Numerical.

Table 3. Free vibration analysis results of hybrid composite shafts.

\begin{tabular}{|c|c|c|c|}
\hline Lay-up orientation & Talib et al. (2010) & Present study & Numerical error $(\%)$ \\
\hline$\left[90_{\text {GF-EP }} / 45_{\text {GF-EP }} /-45_{\text {GF-EP }} / 90_{\text {GF-EP }}\right]$ & 57.61 & 57.81 & 0.35 \\
\hline$\left[45_{\mathrm{GF}-\mathrm{EP}} /-45_{\mathrm{GF}-\mathrm{EP}} / 90_{\mathrm{GF}-\mathrm{EP}} / 0_{\mathrm{GF}-\mathrm{EP}}\right]$ & 57.55 & 57.71 & 0.27 \\
\hline$\left[90_{\text {GF-EP }} / 45_{\text {GF-EP }} /-45_{\text {GF-EP }} / 0_{\text {CF-EP }}\right]$ & 86.85 & 87.38 & 0.61 \\
\hline$\left[0_{\text {CF-EP }} / 45_{\text {GF-EP }} /-45_{\text {GF-EP }} / 90_{\text {GF-EP }}\right]$ & 84.59 & 83.96 & 0.74 \\
\hline
\end{tabular}




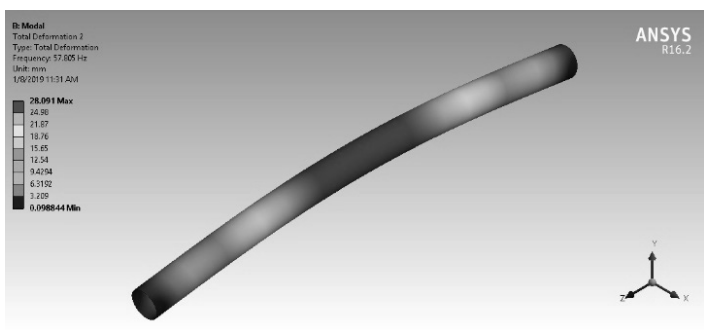

(a)

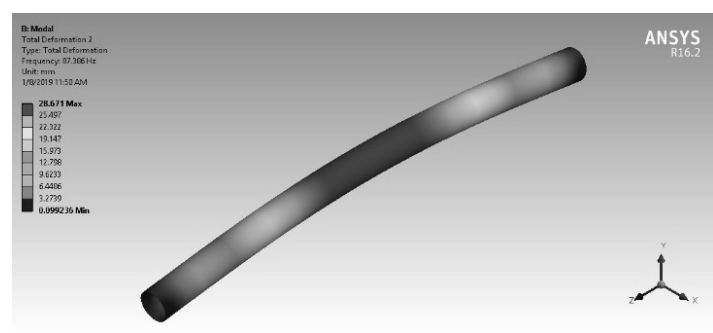

(c)

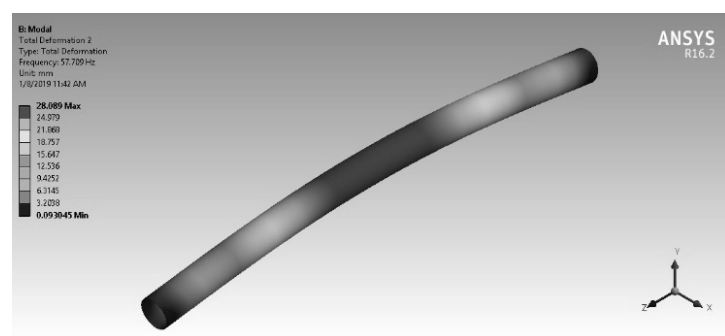

(b)

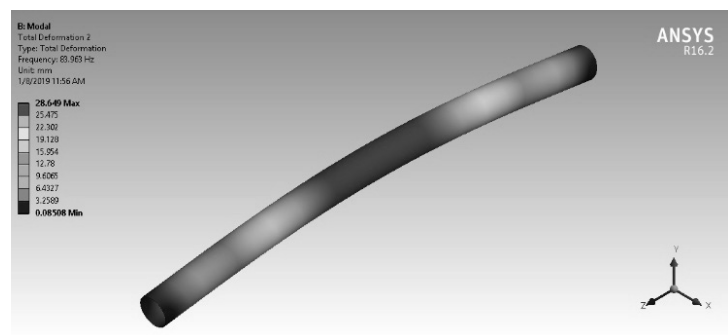

(d)

Figure 4. First mode of natural frequency of the composite tube (a) Lay-up orientation: $\left[90_{\mathrm{GF}-\mathrm{EP}} / 45_{\mathrm{GF}-\mathrm{EP}} /-45_{\mathrm{GF}-\mathrm{EP}} / 90\right.$ GF-EP $]$, (b) Lay-up orientation: [ $\left.45_{\mathrm{GF}-\mathrm{EP}} /-45_{\mathrm{GF}-\mathrm{EP}} / 90_{\mathrm{GF}-\mathrm{EP}} / 0_{\mathrm{GF}-\mathrm{EP}}\right]$, (c) Lay-up orientation: $\left[90_{\mathrm{GF}-\mathrm{EP}} / 45_{\mathrm{GF}-\mathrm{EP}} /-45_{\mathrm{GF}-\mathrm{EP}} / 0_{\mathrm{CF}-\mathrm{EP}}\right]$ and (d) Lay-up orientation: $\left[0_{\mathrm{CF}-\mathrm{EP}} / 45_{\mathrm{GF}-\mathrm{EP}} /-45_{\mathrm{GF}-\mathrm{EP}} / 90_{\mathrm{GF}-\mathrm{EP}}\right]$.

\section{PROBLEM STATEMENT}

The hybrid composite shaft was composed of an aluminum layer and carbon fiber/epoxy composite section. The nonoptimized hybrid composite shaft was considered at this stage. The length of the hybrid composite shaft was 1.30 $\mathrm{m}$. The composite section of the shaft was made of six carbon/epoxy plies, and each ply had a thickness of $0.5 \mathrm{~mm}$. The fiber orientation of the composite section was $[0]_{6}$. The mechanical properties of aluminum and composite layers were given in Table 4. For optimization studies, carbon fiber/epoxy and E-glass/epoxy materials were coded as "1" and "2", respectively. The elastic modulus, poisson ratio, and density of aluminum were assumed as $72 \mathrm{GPa}, 0.33$, and $2700 \mathrm{~kg} / \mathrm{m}^{3}$, respectively. The inner diameter of the hybrid composite shaft and thickness of aluminum layer was selected as 94 and $0.5 \mathrm{~mm}$, respectively. The cost of single carbon fiber/epoxy and E-glass/fiber epoxy ply was assumed as 38.60 and $28.80 £ / \mathrm{m}^{2}$, respectively.

Table 4. Mechanical properties of carbon fiber/epoxy and glass fiber/epoxy composites.

\begin{tabular}{|c|c|c|}
\hline Material & Carbon fiber/epoxy & E-glass/epoxy \\
\hline $\mathrm{E}_{1}(\mathrm{GPa})$ & 131.6 & 43.3 \\
\hline $\mathrm{E}_{2}(\mathrm{GPa})$ & 8.20 & 14.7 \\
\hline $\mathrm{E}_{3}(\mathrm{GPa})$ & 8.20 & 14.7 \\
\hline $\mathrm{G}_{12}(\mathrm{GPa})$ & 4.5 & 4.4 \\
\hline $\mathrm{G}_{23}(\mathrm{GPa})$ & 3.5 & 3.5 \\
\hline $\mathrm{G}_{13}(\mathrm{GPa})$ & 4.5 & 4.4 \\
\hline $\mathrm{v}_{12}, \mathrm{v}_{23}(-)$ & 0.281 & 0.30 \\
\hline$\rho\left(\mathrm{kg} / \mathrm{m}^{3}\right)$ & 1550 & 2100 \\
\hline $\mathrm{Ply} \mathrm{thickness}(\mathrm{mm})$ & 0.25 & 0.25 \\
\hline Cost $\left(£ / \mathrm{m}^{2}\right)^{*}$ & 38.60 & 28.80 \\
\hline
\end{tabular}

*Cost of aluminum: $10.96 £ / \mathrm{m}^{2}$. 


\section{TSAI-WU FAILURE CRITERION}

In this study, the Tsai-Wu failure criterion was used to determine the first-ply-failure in the hybrid composite laminate. The Tsai-Wu failure criterion is one of the most widely used failure criteria developed for anisotropic materials such as unidirectional composites. It has been employed to many composite engineering structures by researchers and designers over the past decades. It has also been successfully incorporated into commercial finite element software packages, such as Abaqus and ANSYS.

The Tsai-Wu failure index (FI) of each composite ply can be calculated. It is assumed that the material safe if $\mathrm{FI}<1$ while the critical condition is predicted when FI $>1$. The Tsai-Wu failure index (FI) of the composite later can be calculated by using Eq. (1).

$$
\begin{aligned}
& F I=F_{1} \sigma_{1}+F_{2} \sigma_{2}+F_{3} \sigma_{3}+F_{11} \sigma_{1}^{2}+F_{22} \sigma_{2}^{2}+F_{33} \sigma_{3}^{2}+F_{44} \sigma_{4}^{2}+ \\
& F_{55} \sigma_{5}^{2}+F_{66} \sigma_{6}^{2}+2 F_{12} \sigma_{1} \sigma_{2}+22 F_{13} \sigma_{1} \sigma_{3}+2 F_{23} \sigma_{2} \sigma_{3}
\end{aligned}
$$

where

$$
\begin{aligned}
& F_{1}=\frac{1}{X_{t}}+\frac{1}{X_{c}} ; F_{2}=\frac{1}{Y_{t}}+\frac{1}{Y_{c}} ; F_{3}=\frac{1}{Z_{t}}+\frac{1}{Z_{c}} \\
& F_{11}=-\frac{1}{X_{t} X_{c}} ; F_{22}=-\frac{1}{Y_{t} Y_{c}} ; F_{33}=-\frac{1}{Z_{t} Z_{c}} \\
& F_{44}=\frac{1}{S_{23}^{2}} ; F_{55}=\frac{1}{S_{13}^{2}} ; F_{66}=\frac{1}{S_{12}^{2}} \\
& F_{12}=-\frac{\sqrt{F_{11} F_{22}}}{2} ; F_{23}=-\frac{\sqrt{F_{22} F_{33}}}{2} ; F_{13}=-\frac{\sqrt{F_{11} F_{33}}}{2}
\end{aligned}
$$

In Equation (2), $X, Y$ and $Z$ are the material strengths in the $\mathrm{x}, \mathrm{y}$ and $\mathrm{z}$ directions, respectively. $t$ and $c$ are corresponds to tensile and compressive, respectively. $S$ is the shear strength of the composite lamina. The tensile, compression, and shear strength values for carbon fiber/epoxy and E glass/epoxy composites were given in Table 5 .

Table 5. Strength values of carbon fiber/epoxy and glass fiber/epoxy composites.

\begin{tabular}{|c|c|c|}
\hline & Carbon fiber/epoxy & E-glass/epoxy \\
\hline $\mathbf{X}_{\mathbf{t}}(\mathbf{M P a})$ & 2000 & 1050 \\
\hline $\mathbf{Y}_{\mathbf{t}}=\mathbf{Z}_{\mathbf{t}}(\mathbf{M P a})$ & 61 & 65 \\
\hline $\mathbf{X}_{\mathbf{c}}(\mathbf{M P a})$ & -1400 & -700 \\
\hline $\mathbf{Y}_{\mathbf{c}}=\mathbf{Z}_{\mathbf{c}}(\mathbf{M P a})$ & -130 & -120 \\
\hline $\mathbf{S}_{\mathbf{x y}}=\mathbf{S}_{\mathbf{x z}}(\mathbf{M P a})$ & 70 & 40 \\
\hline $\mathbf{S}_{\mathbf{y z}}(\mathbf{M P a})$ & 40 & 65 \\
\hline
\end{tabular}

\section{MATHEMATICAL FORMULATION OF THE OPTIMIZATION PROBLEM}

The mathematical formulation of the hybrid drive shaft optimization problem can be described as follows:

Objective function: Minimize (cost, weight)

Design variables: Ply angles; $-90 \leq \theta_{1, \ldots ., n} \leq+90 ; \mathrm{n}=6$ (with a step of $15^{\circ}$ angle, ply orientation $[\Theta]_{6}$ ) (from bottom layer to top), Ply material: carbon fiber/epoxy or E glass/epoxy, Aluminum thickness $\left(t_{\text {aluminum }}\right)=0.5 \mathrm{~mm}-3.0 \mathrm{~mm}$, Length: $1000-1400 \mathrm{~mm}$, The inner diameter $\left(D_{\text {in }}\right): 75-100 \mathrm{~mm}$.

Constraints: Design torque $\geq 3500$ N.m, $1^{\text {st }}$ mode natural frequency $\geq 153 \mathrm{~Hz},\left(\mathrm{FI}_{\max }\right) \leq 0.5$ Factor of safety $(\mathrm{FoS}) \geq 2.0$ 
The torque capacity of the drive shaft for passenger cars should be equal or higher than 3500 N.m. The fundamental bending natural frequency should be higher than $9200 \mathrm{rpm}$ (corresponds to $153 \mathrm{~Hz}$ approximately) to avoid whirling vibration. The outer diameter of the drive shaft is limited to $100 \mathrm{~mm}$. The maximum Tsai-Wu failure index $\left(\mathrm{FI}_{\text {index }}\right)$ calculated for each ply should be less than 0.5 . (Factor of safety $=2$ for static loading). For the torsional buckling, the factor of safety was also considered as 2.0. The factor of safety was calculated by dividing the numerical torsional load by the minimum required torsional buckling load of $3500 \mathrm{~N} . \mathrm{m}$. The design variables were as follows: ply angle, ply material, length and inner diameter of the shaft and aluminum thickness of the hybrid composite shaft.

\section{OPTIMIZATION IN ANSYS WORKBENCH}

In this study, the optimum design variables were determined by using screening method. The number of samples, the number of potential solutions, was considered as 500. Figure 5 shows the project schematic of optimization in ANSYS Workbench. In Cell A, the geometry and finite element model of the composite drive shaft were created. The ply orientations, ply materials, and the other design parameters such shaft diameter and length were defined as input parameters in ACP Pre Module. In Cell B, the first mode natural frequency values of the hybrid composite drive shafts were determined and defined as the one of the output parameters. In Cell C, a torsional moment with a magnitude of 3500 N.m was applied to the one end of the hybrid composite drive shaft. The other end was fixed as in the case of verification study shown in Figure $2 \mathrm{~b}$.

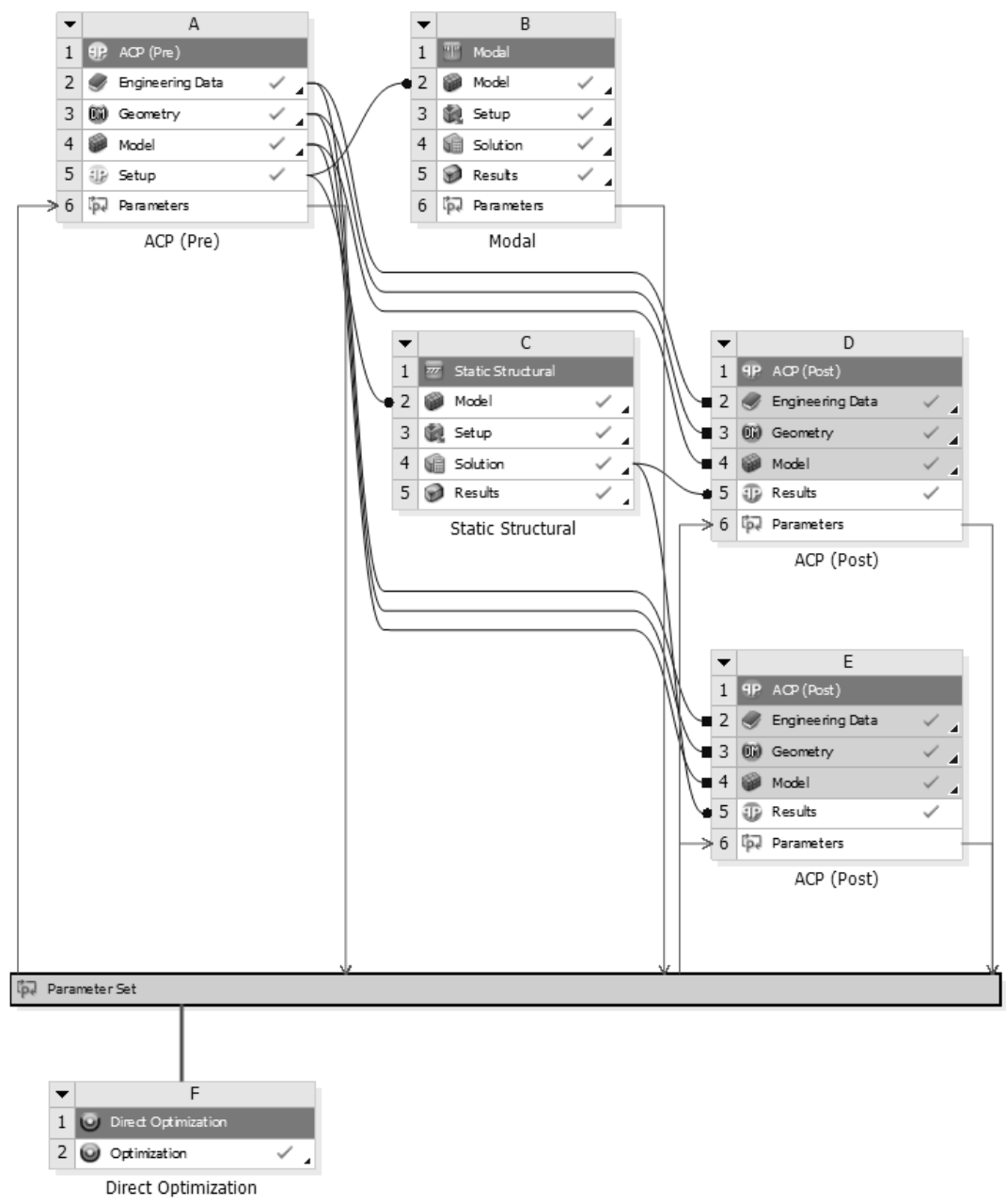

Figure 5. The project schematic of optimization problem in ANSYS Workbench. 
In Cells D and E, the other output parameters of the optimization problem such as weight, cost, and Tsai-Wu failure index were defined and calculated. In Cell F, the optimization method, the objectives, and constraints were defined. Then, the direct optimization using screening method was carried out to find the optimum design parameters for the composite drive shaft. The design parameters were optimized to obtain the most cost-effective solution for the hybrid aluminum/composite drive shaft satisfying the design requirements.

\section{RESULTS AND DISCUSSION}

\section{Effect of parameters on the design of hybrid composite drive shaft}

The effects of ply orientations on the first-mode natural frequency, Tsai-Wu failure index (FI), maximum shear stress, and critical torsional buckling load $\left(\mathrm{T}_{\text {buckling }}\right)$ values were shown in Figure 6 . The variation of $1^{\text {st }}$ mode natural frequency with respect to fiber orientation was shown in Figure 6a. As expected, the highest natural frequency was observed when the fibers were oriented at 0 degree since the bending stiffness of the shaft takes its maximum value at 0 degree. The design constraint of $153 \mathrm{~Hz}$ for the $1^{\text {st }}$ mode natural frequency was redlined in the figure. As can be seen, the required natural frequency value for the shaft can be obtained within the range of -30 and +30 degree. For the initial design with 0 -degree fiber orientation, the required first natural frequency value was satisfied with a value of $234.74 \mathrm{~Hz}$. Under this red line, it is not possible to get required frequency value for the successful design of hybrid composite shaft. The Tsai-Wu failure index vs. fiber orientation plot was shown in Figure 6b. The Tsai-Wu failure index values showed a decreasing trend from 90 degree to 60 degree, at which it takes its minimum, then started to increase with decreasing fiber angle. The highest Tsai-Wu failure index value was noted when the fibers oriented at $0^{\circ}$. This can be attributed to the shear stress variation with the fiber orientation. Figure $6 \mathrm{c}$ shows the variation of maximum shear stress with fiber orientations. The minimum shear stress accumulated in the drive shaft with the angle of \pm 45 degrees whereas the maximum shear stress values were observed at 0 -degree fiber angle. Therefore, the Tsai-Wu failure index takes its maximum values at 0 -degree fiber angle. It can be also seen that, for every fiber angle considered, the Tsai-Wu failure index was higher than the critical value of 0.50. Although the FI value was lower than 1.0 , the factor of safety was assumed as 2 . Therefore, the FI index should be lower than 0.5 for the safe design. Figure $6 \mathrm{~d}$ shows the variation of critical torsional buckling load with respect to the fiber orientation of the hybrid shaft. The critical torsional buckling load decreased with the angle from -90 degree to -15 degree and started to increase when the fiber angle was higher than 15 degree. As can be also seen in this figure, the lowest critical buckling load was obtained at an angle of \pm 15 degree. The critical buckling values were lower than the design torque of 3500 N.m. For the initial design, the fiber angles of \pm 90 and \pm 80 were the fiber angles satisfying the design torque requirement. However, it was not possible to obtain the required natural frequency values higher than $153 \mathrm{~Hz}$ by using these fiber orientations in the design of hybrid composite drive shaft. Taking the fiber angles within range of \pm 90 and \pm 80 degrees would reduce the natural frequency values below $153 \mathrm{~Hz}$. 


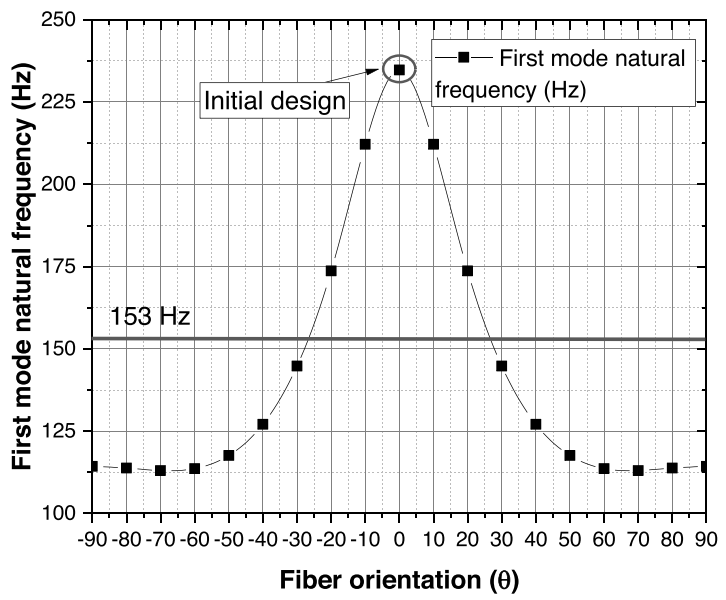

(a)

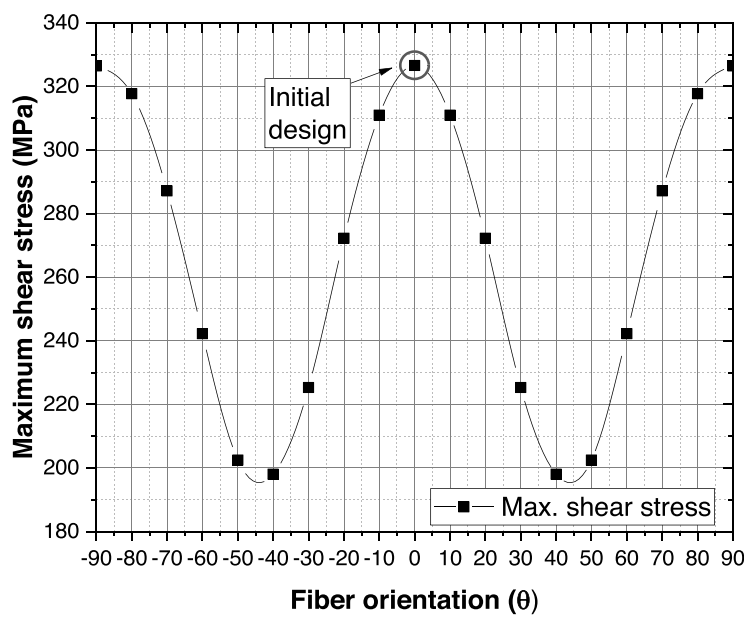

(c)

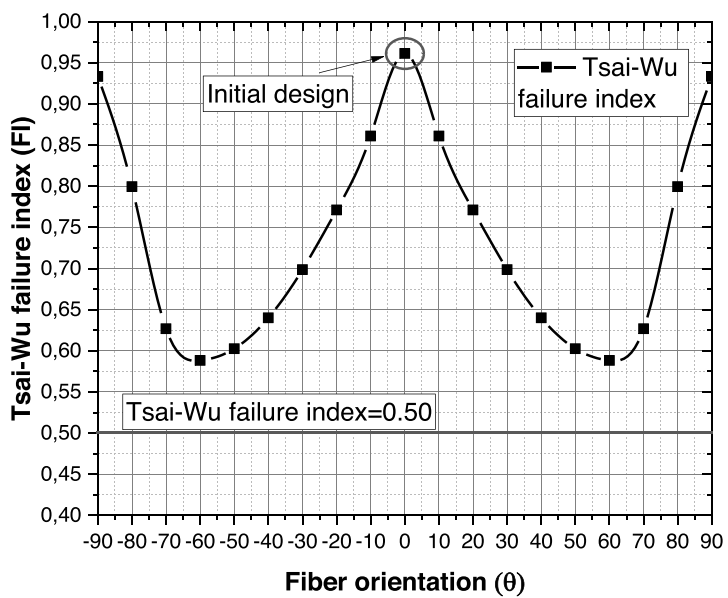

(b)

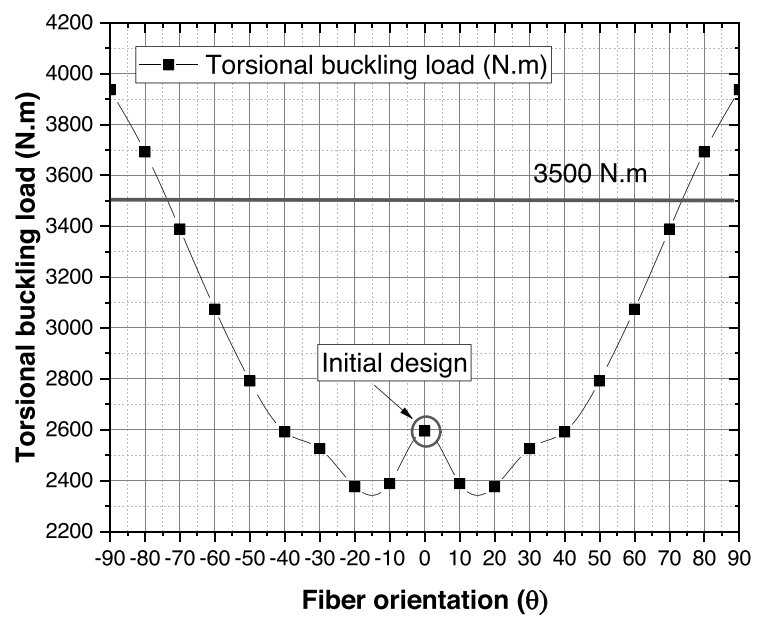

(d)

Figure 6. The effect of ply orientations on the (a) first-mode natural frequency, (b) Tsai-Wu failure index (FI), (c) maximum shear stress, and (d) critical torsional buckling load $\left(\mathrm{T}_{\text {buckling }}\right)$ (Initial design, fiber orientation $[\Theta]_{6}$ ).

For the initial design, the Tsai-Wu failure index and torsional buckling load values were lower than the required values. Therefore, it can be said that the initial design was not a proper design and should be properly optimized for satisfying all design requirements. 


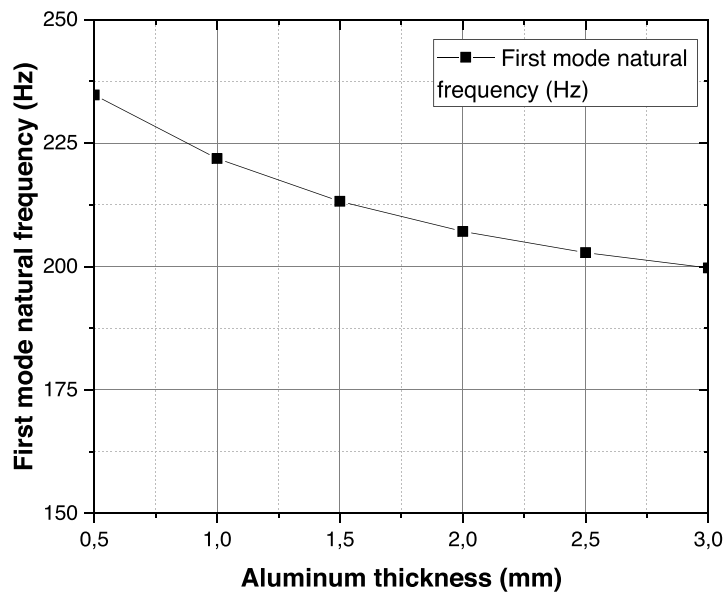

(a)

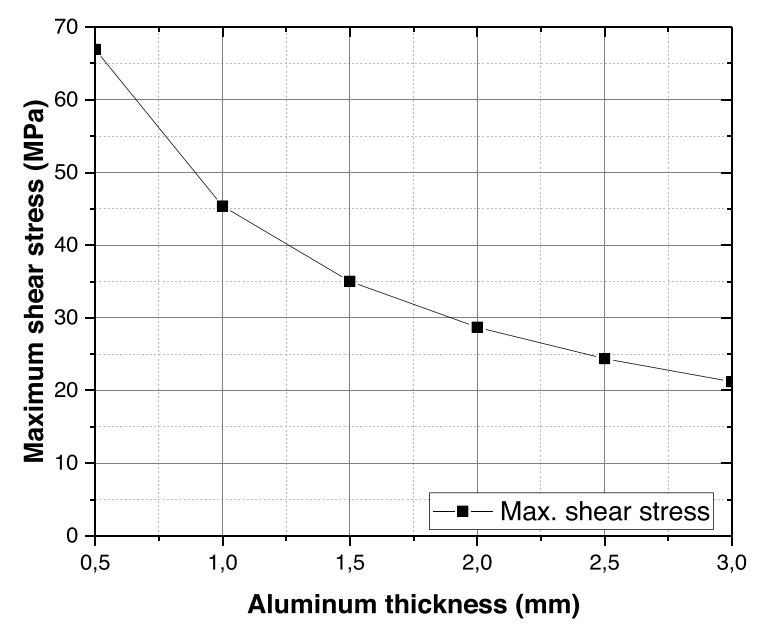

(c)

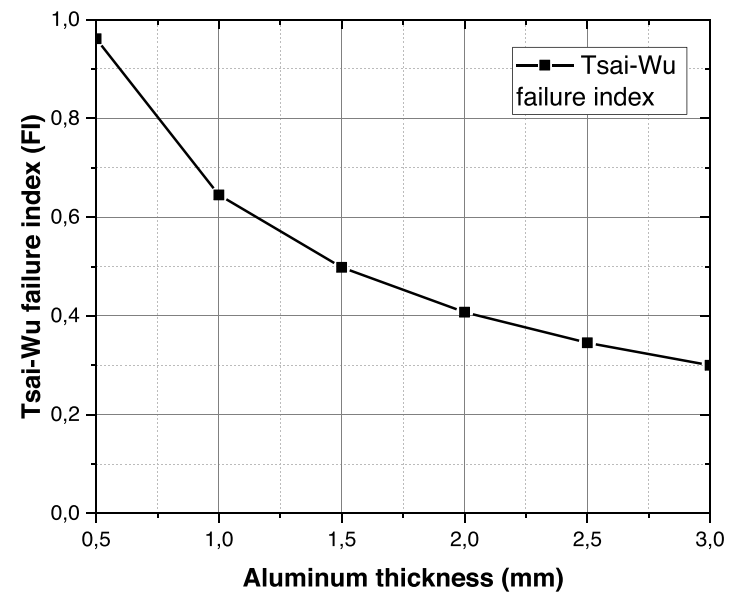

(b)

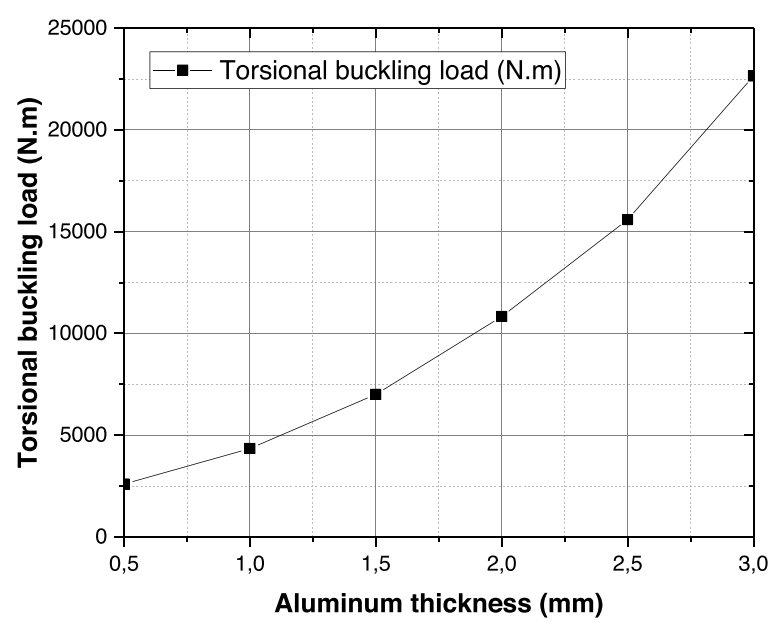

(d)

Figure 7. The effect of aluminum thickness on the (a) first-mode natural frequency, (b) Tsai-Wu failure index (FI), (c) maximum shear stress, and (d) critical torsional buckling load ( $\left.\mathrm{T}_{\text {buckling }}\right)$.

The effects of aluminum thickness on the first-mode natural frequency, Tsai-Wu failure index (FI), maximum shear stress, and critical torsional buckling load $\left(\mathrm{T}_{\text {buckling }}\right)$ values were shown in Figure 7 . As can be seen in Figure $7 \mathrm{a}$, the first mode natural frequency values decreased from $234.74 \mathrm{~Hz}$ to 199.71 with an increase of aluminum thickness from $0.5 \mathrm{~mm}$ to $3.0 \mathrm{~mm}$. This corresponds to about $15 \%$ decrease in natural frequency values. The increase in aluminum thickness resulted in an increase in weight, and therefore, a decrease in natural frequency. The Tsai-Wu failure index and the maximum shear stress values decreased with an increase in the aluminum thickness as shown in Figure $7 \mathrm{~b}$ and Figure 7c. The torsional buckling load of the hybrid shaft seemed to be the mostly affected parameter by of the aluminum thickness among the other parameters considered. The torsional buckling load was increased from $2595 \mathrm{~N}$. $\mathrm{m}$ to $22653 \mathrm{~N} . \mathrm{m}$ when the aluminum thickness was increased from $0.5 \mathrm{~mm}$ to $3.0 \mathrm{~mm}$. The critical torsional buckling load of the shaft with $3.0 \mathrm{~mm}$-thick aluminum was almost 8 times higher as compared to the shaft having an aluminum with a thickness of $0.5 \mathrm{~mm}$. 


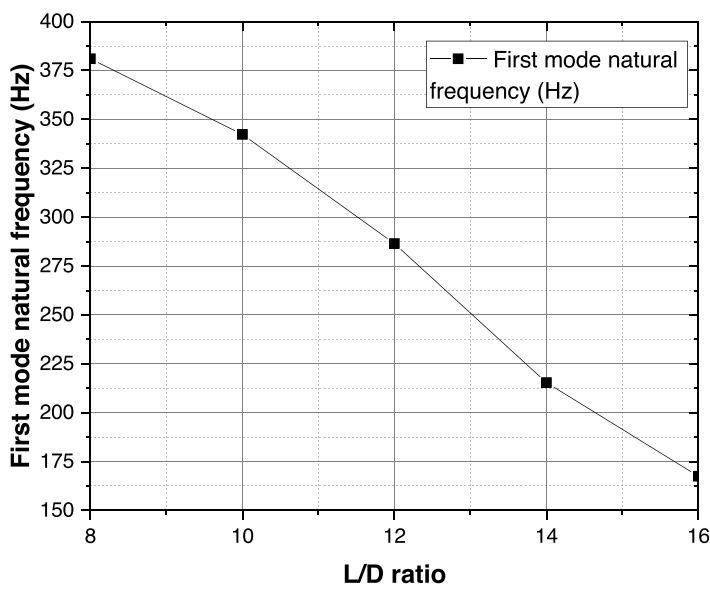

(a)

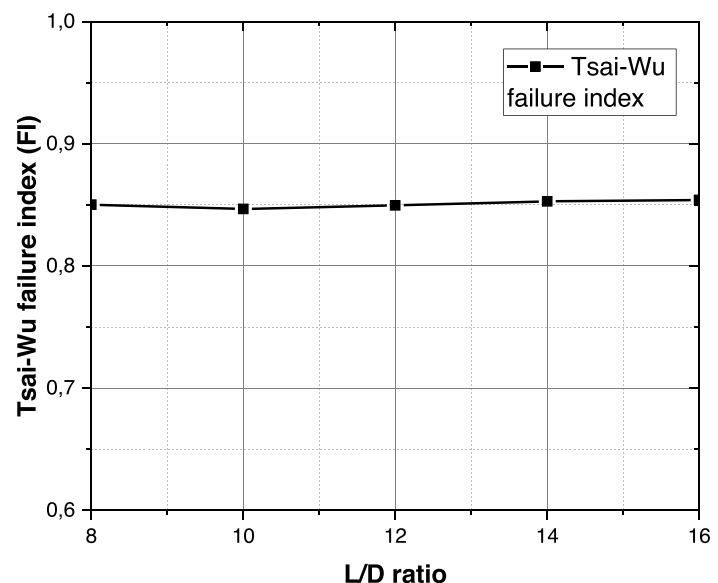

(b)

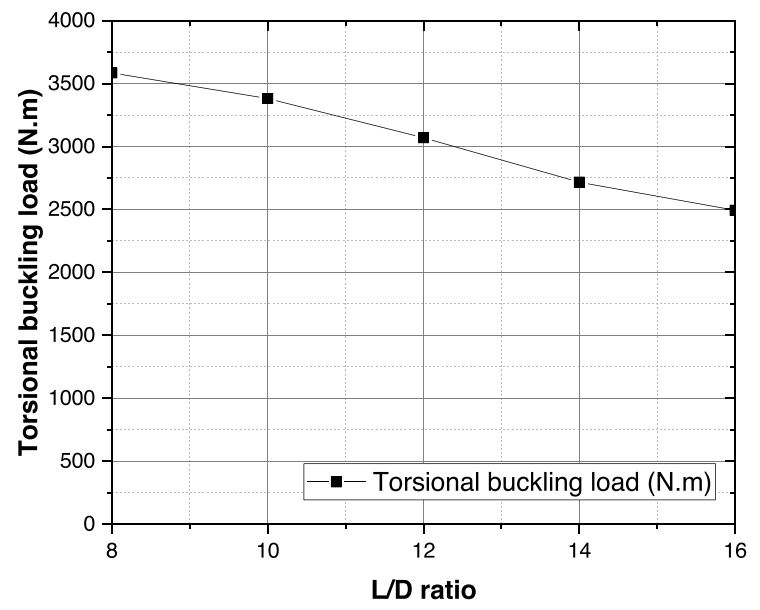

(c)

Figure 8. The effect of L/D ratio on the (a) first-mode natural frequency, (b) Tsai-Wu failure index (FI) and (c) critical torsional buckling load ( $\left.\mathrm{T}_{\text {buckling }}\right)\left(\mathrm{D}_{\text {inner }}=100 \mathrm{~mm}\right)$.

Although, the required critical torsional buckling load could be obtained by increasing the aluminum thickness, the weight penalty due to thicker aluminum should be also considered in the optimum design of hybrid composite drive shaft. Figure 8 shows the effect of L/D ratio on the first-mode natural frequency, Tsai-Wu failure index (FI) and critical torsional buckling load of the hybrid drive shaft. The L/D ratio had a significant effect on the first mode natural frequency and critical torsional buckling values. The higher L/D ratio caused a reduction in the natural frequency and critical torsional buckling values whereas the Tsai-Wu failure index was not affected by the $\mathrm{L} / \mathrm{D}$ ratio.

\section{Optimization results}

Table 6 shows the obtained minimum and maximum values for weight, cost, frequency and Tsai-Wu failure index values after optimization run. It was observed that the first mode natural frequency values were in the range between $96.62 \mathrm{~Hz}$ and $301.86 \mathrm{~Hz}$. The Tsai-Wu failure index values were changed from 0.19 to 1.74 within the possible solutions of optimization problem. The weight of the shaft was changed from $0.867 \mathrm{~kg}$ to 4.532 due to the aluminum thickness and selection of carbon fiber/epoxy or E glass fiber/epoxy plies in the lamination sequence of the shaft. Weight and cost values were also changed due to ply material, the inner diameter and length of the shaft. 
Table 6. Calculated minimum and maximum values for each output parameters.

\begin{tabular}{|l|c|c|c|c|}
\hline & Weight (kg) & Cost (f) & $\begin{array}{c}\text { 1st mode natural } \\
\text { frequency (Hz) }\end{array}$ & $\begin{array}{c}\text { Tsai-Wu failure } \\
\text { index }\end{array}$ \\
\hline Calculated minimum & 0.867 & 49.72 & 96.62 & 0.19 \\
\hline Calculated maximum & 4.532 & 96.96 & 301.86 & 1.74 \\
\hline
\end{tabular}

Table 7 shows the optimization results, which satisify the design requirement of the hybrid composite drive shaft. For the minimum weight design, the optimum fiber orientations were determined as $-45 / 15 / 90 / 45 /-45 / 15$. The $\mathrm{L} / \mathrm{D}$ ratio aluminum thickness should be selected as 12.73 and $1.1225 \mathrm{~mm}$, respectively. The Tsai-Wu failure index was calculated as 0.4588 and corresponding factor of safety was determined as 2.179 , which satisfies the design requirement. The critical torsional buckling load was also in the range of safety margin ( $\mathrm{FoS}=2.108)$.

Table 7. Optimization results.

\begin{tabular}{|c|c|c|c|c|}
\hline & $\begin{array}{c}\text { Preliminary } \\
\text { design }\end{array}$ & $\begin{array}{c}\text { Minimum } \\
\text { weight design } \\
\text { DP-1 }\end{array}$ & $\begin{array}{l}\text { Minimum } \\
\text { cost design } \\
\text { DP-2 }\end{array}$ & $\begin{array}{c}\text { Combined weight and } \\
\text { cost optimization } \\
\text { DP-3 }\end{array}$ \\
\hline Length ( $L$, mm) & 1300 & 1127.74 & 1014.32 & 1018.4 \\
\hline Inner diameter (D, mm) & 94 & 88.598 & 79.322 & 91.576 \\
\hline $\mathrm{L} / \mathrm{D}$ ratio & 13.83 & 12.73 & 12.78 & 11.20 \\
\hline Aluminum thickness (mm) & 0.5 & 1.1225 & 2.7925 & 1.6075 \\
\hline Ply orientations* & $0 / 0 / 0 / 0 / 0 / 0$ & $-45 / 15 / 90 / 45 /-45 / 15$ & $60 /-90 / 60 / 15 / 60 /-30$ & $45 / 60 /-15 / 30 /-60 /-90$ \\
\hline Ply materials*,** & $1 / 1 / 1 / 1 / 1 / 1$ & $1 / 1 / 1 / 1 / 1 / 2$ & $2 / 2 / 2 / 1 / 1 / 2$ & $2 / 2 / 1 / 2 / 1 / 1$ \\
\hline Weight (kg) & 1.4102 & 1.7234 & 2.6342 & 2.0726 \\
\hline $\begin{array}{c}\text { \% weight decrease } \\
\text { (Compared to the steel } * * * \\
\text { counterpart) }\end{array}$ & $\begin{array}{c}77.00 \\
(6.0244 \mathrm{~kg})\end{array}$ & $\begin{array}{c}73.30 \\
(6.456 \mathrm{~kg})\end{array}$ & $\begin{array}{c}69.04 \\
(8.511 \mathrm{~kg})\end{array}$ & $\begin{array}{c}70.98 \\
(7.1435 \mathrm{~kg})\end{array}$ \\
\hline $\operatorname{Cost}(\mathfrak{f})$ & 93.08 & 73.022 & 51.369 & 62.421 \\
\hline Cost/weight (£/kg) & 66.00 & 42.37 & 19.50 & 30.11 \\
\hline $\begin{array}{c}\text { 1st mode natural } \\
\text { frequency values }(\mathrm{Hz})\end{array}$ & 234.74 & 196.79 & 213.26 & 235.29 \\
\hline Tsai-Wu failure index (-) & 0.96126 & 0.4588 & 0.48198 & 0.45393 \\
\hline $\begin{array}{c}\text { Torsional buckling load } \\
\text { (N.m) }\end{array}$ & 2595.1 & 7378.3 & 21490 & 13226 \\
\hline $\begin{array}{c}\text { Factor of safety } \\
\text { (FoS-static loading) }\end{array}$ & 1.040 & 2.179 & 2.074 & 2.202 \\
\hline $\begin{array}{c}\text { Factor of safety } \\
\text { (FoS-buckling load) }\end{array}$ & 0.741 & 2.108 & 6.14 & 3.778 \\
\hline
\end{tabular}

*From bottom layer to top layer, **CF/EP: 1, EG/EP: 2. ***The density of steel was assumed as $7850 \mathrm{~kg} / \mathrm{m}^{3}$. 
The first mode natural frequency value of DP-1 was determined as $196.79 \mathrm{~Hz}$, which is about $29 \%$ higher than the required first mode natural frequency value. The weight and cost of the DP-1 were calculated as $1.7234 \mathrm{~kg}$ and 73.02 $£$, respectively. The hybrid composite shaft with the minimum weight was made of 5 plies CF/EP and 1 ply of EG/EP. For the minimum cost design, the optimum fiber orientations were determined as 60/-90/60/15/60/-30. The Tsai-Wu failure index was calculated as 0.48198 and corresponding factor of safety was determined as 2.0474 , which satisfies the design requirement. The critical torsional buckling load was also in the range of safety margin ( $\mathrm{FoS}=6.14)$. As can be seen, this design is the safest design in terms of critical torsional buckling load. As expected, for minimum cost design, the number of EF/EP layers was increased to 4 as compared to the minimum weight design, in which there was one single EF/EP layer. To sustain the required torsional load of $3500 \mathrm{~N} . \mathrm{m}$, the aluminum thickness of the hybrid composite shaft was increased from 1.1225 to $2.7925 \mathrm{~mm}$. This increase led to significant increase in the critical torsional buckling load values. The first mode natural frequency was determined as $213.26 \mathrm{~Hz}$, which is $29 \%$ higher than the required natural frequency of $153 \mathrm{~Hz}$. For the minimum weight and cost design, the fiber orientations were determined as 45/60/-15/30/-60/-90. The hybrid composite shaft of DP-3 was made of 3 plies CF/EP and 3 plies of EG/EP. The Tsai-Wu failure index was calculated as 0.45393 and corresponding factor of safety was determined as 2.202, which satisfies the design requirement. This design seems to be safer than DP-2 in terms of static loading. The critical torsional buckling load was determined as $13136 \mathrm{~N} . \mathrm{m}$, which is also in the range of safety margin (FoS=3.78). Also, it is possible to obtain a cost-effective solution for hybrid composite drive shaft, which is 1.8 times safer in terms of torsional buckling load as compared to DP-2. By comparing DP-2 and DP-3 design, the weight increase was about $22 \%$ whereas the cost gain was about $36 \%$. As compared to the initial design, the selection of DP-2 parameters decreased the total cost of the hybrid composite shaft from 66.00 to 30.11 about 55\%. As compared to steel counterpart, it is possible to obtain a drive shaft with a weight reduction of $70.98 \%$. Table 8 shows a comparison of the maximum von Mises stress and shear strain values for the preliminary design and the three optimum solutions, i.e. DP-1, DP-2 and DP-3. The maximum von Mises stress was determined as $565.59 \mathrm{MPa}$ for preliminary design whereas the maximum von Mises stress was determined as 275.42 MPa, 168.12 MPa, 190.11MPa for the DP-1, DP-2 and DP-3, respectively. The overall percentage differences of maximum von-Mises stresses between the preliminary design and optimal design were calculated as $69 \%, 109 \%$, and $99.4 \%$ for the DP-1, DP-2, and DP-3, respectively. The von Mises stresses of presented three optimal solutions was significantly lower than that of preliminary design. The maximum shear strain was determined as $0.017565 \mathrm{~mm} / \mathrm{mm}$, whereas the maximum shear strain was determined as $0.0052769 \mathrm{~mm} / \mathrm{mm}, 0.0053416 \mathrm{~mm} / \mathrm{mm}$, and $0.005792 \mathrm{~mm} / \mathrm{mm}$ for the DP-1, DP-2, and DP-3, respectively.

Table 8. Comparison of von Mises stress and maximum shear strain values for the preliminary design and three optimal solutions.

\begin{tabular}{|c|c|c|c|c|}
\hline & $\begin{array}{c}\text { Preliminary } \\
\text { design }\end{array}$ & $\begin{array}{c}\text { Minimum } \\
\text { weight design } \\
\text { DP-1 }\end{array}$ & $\begin{array}{c}\text { Minimum } \\
\text { cost design } \\
\text { DP-2 }\end{array}$ & $\begin{array}{c}\text { Combined weight } \\
\text { and cost optimization } \\
\text { DP-3 }\end{array}$ \\
\hline Length (L, mm) & 1300 & 1127.74 & 1014.32 & 1018.4 \\
\hline Inner diameter (D, mm) & 94 & 88.598 & 79.322 & 91.576 \\
\hline L/D ratio & 13.83 & 12.73 & 12.78 & 11.20 \\
\hline Aluminum thickness (mm) & 0.5 & 1.1225 & 2.7925 & 1.6075 \\
\hline Ply orientations* & $0 / 0 / 0 / 0 / 0 / 0$ & $-45 / 15 / 90 / 45 /-45 / 15$ & $60 /-90 / 60 / 15 / 60 /-30$ & $45 / 60 /-15 / 30 /-60 /-90$ \\
\hline Ply materials*** & $1 / 1 / 1 / 1 / 1 / 1$ & $1 / 1 / 1 / 1 / 1 / 2$ & $2 / 2 / 2 / 1 / 1 / 2$ & $2 / 2 / 1 / 2 / 1 / 1$ \\
\hline $\begin{array}{c}\text { Maximum von Mises stress } \\
\text { (MPa)**** }\end{array}$ & 565.59 & 275.42 & 168.12 & 190.11 \\
\hline $\begin{array}{c}\text { Maximum shear strain } \\
\text { (mm/mm)*** }\end{array}$ & 0.017565 & 0.0052769 & 0.0053416 & 0.005792 \\
\hline
\end{tabular}

*From bottom layer to top layer, **CF/EP: 1, EG/EP: 2 , ***The applied torque is $3500 \mathrm{~N} / \mathrm{m}$. 
The maximum shear strain values of three optimal solutions were significantly lower than those of preliminary design. It can be said that all the three optimal solutions presented in this study provided a safer design for a hybrid composite shaft with higher stifness and torsional buckling capacity.

\section{CONCLUSION}

In this study, the design optimization of a hybrid aluminum/composite drive shaft subjected to torsion was carried out using ANSYS software package. The numerical validation of finite element (FE) model was carried out by means of theoretical, experimental, and numerical studies in the literature. The ply material, lay-up orientations, and thickness of aluminum layer were considered as design variables. The geometric parameters in design were the length and inner diameter of the drive shaft. Two important design constraints, the minimum first mode natural frequency and design torque, were considered to satisfy the design requirements of a rear-wheel drive shaft used in automotive industry. The optimum design variables were determined by using screening method. The following results could be drawn:

- The natural frequency increased with decreasing the fiber orientation angle. The decrease in the fiber angle led to an increase in the modulus along the length of the shaft. The fiber orientation has a significant effect on the natural frequency values.

- Fibers orientation angle has a significant effect on the buckling torque. To increase the critical buckling load, the fibers must be placed at \pm 90 degree to obtain highest elastic modulus at radial direction.

- The thickness of aluminum has no significant effect on the first mode natural frequency; on the other hand, the critical buckling load and Tsai-Wu failure index values are significantly affected by the aluminum. The thicker aluminum led to safer design in terms of static loading and buckling load.

- The fiber orientation and aluminum thickness are the dominant parameters that drive the optimal solution for the design of hybrid composite drive shafts.

- The optimum design parameters were determined by direct optimization method. With selecting correct design parameters, it is possible to obtain a safer hybrid composite drive shaft. The direct optimization methodology can be used by designers to select design and geometrical variables including ply material, ply orientations, aluminum thickness, and the design constraints.

\section{REFERENCES}

Badie, M.A., Mahdi, E. \& Hamouda A.M.S. 2011. An investigation into hybrid carbon/glass fiber reinforced epoxy composite automotive drive shaft. Materials and Design, 32: 1485-1500, 2011.

Bauchau, O.A., Bryan, P.S. \& Peck, A.W. 1988. Torsional buckling analysis and damage tolerance of graphite/epoxy shafts. Journal of Composite Materials, 22(3): 258-270.

Bert, J.W. \& Kim, C.D. 1995. Analysis of buckling of hollow laminated composite drive shafts. Composites Science and Technology, 53: 343-351.

Bijagare, A.A., Mehar B.G. \& Mujbaile, V.N. 2012. Design Optimization \& Analysis of Drive Shaft. VSRD International Journal of Mechanical, Automobile \& Production Engineering, 2(6): 210-215.

Cho, D.H. \& D.G. Lee. 1998. Manufacturing of co-cured Aluminum composite shafts with compression during co-curing operation to reduce residual thermal stresses. Journal of Composite Materials, 32: 1221-1241.

Khalkhali A, Nikghalb E, Norouzian M. 2015. Multi-objective Optimization of Hybrid Carbon/Glass Fiber Reinforced Epoxy Composite Automotive Drive Shaft. IJE Transactions A: Basics 28(4): 583-592.

Kim, H.S. \& D.G. Lee, 2005. Optimal Design of the Press Fit Joint for a Hybrid Aluminum/Composite Drive Shaft. Composite Structures, 70: 33-47.

Lee, D.G., Kim, H.S., Kim. J.W. \& Kim. J.K. 2004. Design and manufacture of an automotive hybrid aluminum/composite drive shaft. Composite Structures, 63: 87-99. 
Montagnier, O. \& Hochard. Ch. 2013. Optimisition of hybid high-modulus/high-strength carbon fibre reinforced plastic composite drive shafts. Materials and Design, 46: 88-100.

Rastogni, N. 2004. Design of composite drive shafts for automotive applications, SAE, Technical Paper Series, 2004-01-0485.

Reimpell, J., Stroll, H. \& Betzler J. 2001. The automotive chassis: engineering principles. 2nd Edition Butterworth-Heinemann.

Sevkat, E., Tumer, H., Kelestemur, M.H. \& Dogan S. 2014. Effect of torsional strain-rate and lay-up sequences on the performance of hybrid composite shafts. Materials and Design, 60: 310-319.

Shokrieh M.M., Hasani, A. \& Lessard L.B. 2004. Shear buckling of a composite drive shaft under torsion. Composite Structures, 64(1): 63-69.

Talib, A.R., Ali, A., Badie, M.A., Lah, N.A.C \& Golestaneh, A.F. 2010. Developing a hybrid, carbon/glass fiber-reinforced, epoxy composite automotive drive shaft. Materials and Design, 31: 514-521.

Tariq, M., Nisar, S., Shah, A., Akbar, S., Khan, M.A. \& Khan, S.Z. 2018. Effect of hybrid reinforcement on the performance of filament wound hollow shaft. Composite Structures, 184: 378-87. 